\title{
Article \\ Stakeholder Expectation of Corporate Social Responsibility Practices: A Case Study of PWiK Rybnik, Poland
}

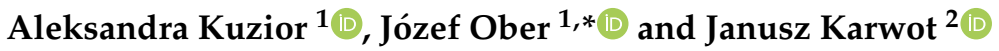 \\ 1 Department of Applied Social Sciences, Faculty of Organization and Management, \\ Silesian University of Technology, Roosevelt Str. 26-28, 41-800 Zabrze, Poland; Aleksandra.Kuzior@polsl.pl \\ 2 Sewage and Water Supply Ltd., Pod Lasem 62, 44-210 Rybnik, Poland; karwotj@interia.pl \\ * Correspondence: Jozef.Ober@polsl.pl; Tel.: +48-322-777-323
}

Citation: Kuzior, A.; Ober, J.; Karwot, J. Stakeholder Expectation of Corporate Social Responsibility Practices: A Case Study of PWiK Rybnik, Poland. Energies 2021, 14, 3337. https://doi.org/10.3390/ en14113337

Academic Editor: Patrycja Hąbek

Received: 22 April 2021

Accepted: 4 June 2021

Published: 6 June 2021

Publisher's Note: MDPI stays neutral with regard to jurisdictional claims in published maps and institutional affiliations.

Copyright: (c) 2021 by the authors. Licensee MDPI, Basel, Switzerland. This article is an open access article distributed under the terms and conditions of the Creative Commons Attribution (CC BY) license (https:// creativecommons.org/licenses/by/ $4.0 /)$.

\begin{abstract}
Practices of corporate social responsibility (CSR), especially in organizations providing key services, related to the supply of fuel, water and energy, are extremely important from the point of view of identifying stakeholders with the functioning of enterprises in line with the principles of a closed loop economy. The article discusses the origins and evolution of the concept of corporate social responsibility, with particular emphasis on the water supply and sewage industry. The research problem was the perception and expectations of stakeholders toward prosocial activities of PWiK Rybnik (Sewage and Water Supply Ltd. Rybnik). The hypothesis assumed in the study was that the external stakeholders of PWIK Rybnik positively assess the company's involvement in the tasks carried out as part of corporate social responsibility, they notice the involvement in educational activities and additional initiatives of PWIK that improve the quality of life of its inhabitants. For the purpose of this study, a quantitative method was used. For the purpose of the survey, the authors' questionnaire "Survey of customers' opinions on the activities undertaken by PWiK Rybnik" was created. The surveys conducted confirmed the hypothesis that the external stakeholders of PWIK Rybnik positively assess the company's involvement in the tasks performed as part of corporate social responsibility; they notice the involvement in educational activities and additional initiatives of PWIK that improve the quality of life of its inhabitants. The results of the research made it possible to formulate guidelines for the operation of water supply and sewage companies in accordance with corporate social responsibility in the light of the opinions of their stakeholders.
\end{abstract}

Keywords: corporate social responsibility; CSR; water and sewage industry; stakeholders; environmental education; quality of life; sustainable development; closed loop economy

\section{Introduction}

Recent years have brought great interest of enterprises in the corporate social responsibility (CSR) idea. Catalogs of good practices describe various initiatives undertaken as part of social responsibility [1-3], although the motivations of social involvement are very different; usually these are promotional reasons and the need to create a positive image of the company, while occasionally there is involvement of companies in solving social problems for ethical reasons $[3,4]$. CSR in enterprises of key importance for the safety of functioning of societies acquires particular significance. According to the concept of corporate governance [5], information necessary for decision making, including first of all good practices, is important and should be made available to investors and other stakeholders. According to research [6], the dissemination of such information is mainly of interest to companies that achieve the best results in the field of environmental protection, thus providing such information on the environment improves their reputation $[7,8]$. It is also worth noting that there is a significant gap between the theory and practice of CSR communication [9], which means that the values declared by companies may be perceived differently by stakeholders. Therefore, the verification of declarations made by companies 
about their CSR activities in relation to the actual perception by stakeholders seems to be extremely important. The research carried out serves this purpose of verifying the actual involvement of the company in CSR activities, and verifies the research hypothesis and the formulated research problem, which concerns the perception and expectations of stakeholders towards PWiK Rybnik's prosocial activities.

Enterprises providing essential services, connected with fuel, water and energy supply, have important social and environmental functions to perform. Therefore, they cannot focus solely on economic profit. The article is devoted to water and sewage enterprises, which occupy a special place in the socioeconomic system for several important reasons. First, they manage and govern the natural resources of drinking water, which in many regions of the world are scarce resources. Second, the water resources they manage are a basic and necessary condition of life for humans and other living organisms, and their correct physical and chemical parameters and availability affect the quality of this life [10]. Third, they are responsible for the condition of the environment in the context of wastewater treatment. Fourth, they have an impact through environmental education (if they undertake such) on shaping the environmental awareness of the society, and due to the shrinking drinking water resources (locally and globally), they consciously undertake actions aimed at rational management of water resources in cooperation with stakeholders.

There is no doubt that life on the planet Earth would not be possible if it lacked water, which is needed to secure basic biological functions of living organisms. Rational management of water resources is part of a broader context of sustainable development, in which corporate social responsibility is a kind of tool supporting the implementation of sustainable development goals. Hence, it is important to include CSR assumptions in the development strategy of enterprises. Enterprises do not operate in a social void, therefore it is important to orient their activities towards stakeholders. The evolution of the CSR idea has taken place from philanthropic activity, through taking action by enterprises, taking into account the objectives and values of society, to creating value and respecting the expectations of stakeholders. According to the message of the special issue of Energies, "Integrated Approaches for Enterprise Sustainability," an integrated approach to corporate sustainability requires taking into account the various stakeholder groups in companies' activities. In the case of a water and sewage company operating in a specific area, the most important stakeholder group will be the local community for which the company provides services. Hence, the empirical research undertaken by the authors of this article, was focused precisely on this group of stakeholders, verifying the hypothesis that external stakeholders of PWIK Rybnik positively assess the company's involvement in the tasks carried out as part of corporate social responsibility; they notice the involvement in educational activities and additional initiatives of PWIK that improve the quality of life of its inhabitants.

The structure of the remaining parts of the article begins with a literature review that presents the history of development and the main assumptions of corporate social responsibility (CSR), and discusses patterns and practical activities associated with it, with particular emphasis on the water supply and sewage industry. In the next part, the research methodology and results are presented along with a discussion. The paper concludes with a summary of cognitive and practical conclusions, as well as limitations and opportunities for future research.

\section{Literature Review}

The concept of corporate social responsibility was constituted on the basis of various socioeconomic experiences. Corporate social responsibility was developed in the United States. Its origins can be found in the 19th century philanthropic tradition. In fact, the impulse for change came from social dissatisfaction and opposition of state officials to the unfair business practices of the US economic tycoons, who repeatedly violated employee rights and evaded paying taxes. Academic discussions and research on corporate social responsibility date back to the 1950s. The work titled Social Responsibilities of the 
Businessman by H.R. Bowen contains the first definition of social responsibility, referring to the obligations of entrepreneurs to society [11]. J.W. McGuire paid attention to the responsibility of enterprises towards society [12]. On the other hand, S.P. Sethi in his considerations distinguished the social obligations of enterprises: social obligation-to meet legal requirements, social responsibility-activities in accordance with social norms and social responsiveness_-taking actions to meet social needs [13]. In Europe, as well as in Poland, the most popular is the concept of A.B. Carroll. In its original form, Carroll indicated that corporate social responsibility should include economic obligations, legal obligations, ethical obligations and discretionary obligations [14]. Later, Carroll included economic responsibility, legal responsibility, ethical responsibility and philanthropic responsibility in his CSR pyramid [15]. Recently, the most popular approach to CSR is in the context of stakeholder theory. From an ethical point of view, the understanding of the idea of social responsibility can be considered in three basic areas:

- Respecting human rights-e.g., P.H. Werhane's approach to corporate social responsibility [16], referring to the ethics of human rights and Kantian understanding of the science of morality, assuming that every human being has the right to respect for their dignity, and that all people are entitled to basic human rights.

- Social contract-e.g., in the views of T. Donaldson and L. Preston [17] the ethics of social contract, deal, agreement is at the core of social responsibility.

- Developing virtues-e.g., the understanding of corporate social responsibility in the work previously mentioned by A.B. Carroll [15,18], or R.C. Solomon [19-21] and E. Hartman [22], referring to virtue ethics in the Aristotelian sense [23].

The last decade has also brought greater interest of researchers in the issues of corporate social responsibility. According to the SCOPUS database, for the query corporate AND social AND responsibility the system finds 22,241 records (data for the years 1957-2021, access date 1 April 2021), with 845 articles already published for the first quarter of 2021. Taking into account the growth dynamics of publications with a similar quarterly increase, it can be estimated that for the query corporate AND social AND responsibility in 2021 the number of records may reach 3380 publications. The dynamics of growth in the number of publications related to corporate social responsibility is shown in Figure 1. For the water AND sewage AND company records, the number of results is 1217. The number of publications for the query corporate AND social AND responsibility AND water AND sewage is much smaller. The system found only six such publications, and for the query corporate AND social AND responsibility AND water AND sewage AND company there are only two results.

By far the broadest approach to the issues analyzed in this article is found in two publications selected on the basis of the records corporate AND social AND responsibility AND water AND sewage AND company.

In the article "Assessment of communication CSR by Polish water and sewage companies", the authors focused their research on communicating CSR. The authors surveyed 510 water supply and sewage companies in Poland. On the basis of empirical studies analyzing the content of the concept of social responsibility published on enterprises' websites, it was found that $63 \%$ of the surveyed enterprises did not inform about the implementation of activities compliant with the CSR concept. The conclusion of the study indicates that the surveyed enterprises do not at all, or to a very limited extent, carry out the task of informing about the CSR activities undertaken, and that in Polish water and sewage enterprises, there is no connection between the implementation of formalized management systems and the implementation of the CSR concept [24]. 


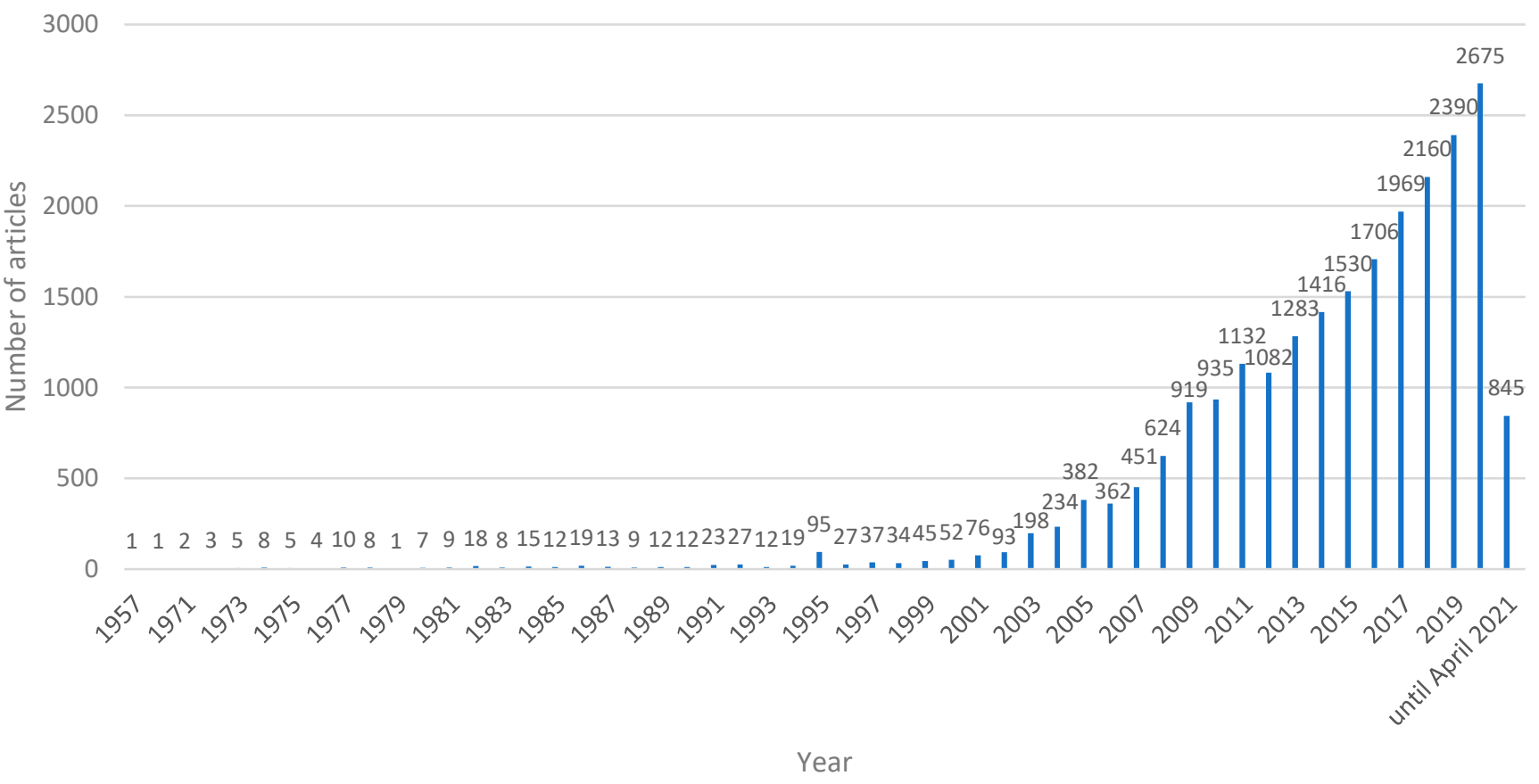

Figure 1. Publications on corporate social responsibility according to the SCOPUS database for the query corporate AND social AND responsibility. Source: Own study based on data from Scopus database (accessed on 1 April 2021).

The second article cited according to the above keywords refers to the monitoring and assessment of threats to the water environment (in particular, chemical pollution), which is related to the implementation of the objectives of sustainable development and the implementation of tasks under corporate social responsibility (CSR). The authors proposed the simulation model AIST-SHANEL (National Institute of Advanced Industrial Science and Technology-Standardized Hydrology-Based Assessment) for monitoring water quality in rivers [25].

The idea of corporate social responsibility is closely related to the concept of sustainable development. Chapter 30 of Agenda 21 [26] specifies, among others, the issues of responsible entrepreneurship, development of responsible business, transnational corporations, industry and small and medium-sized enterprises. The basic guideline for the implementation of CSR assumptions is to create a stable political and legal framework, which on the one hand obliges, and on the other encourages companies to responsible and effective actions, based on more efficient production processes, cleaner technologies and proecological procedures throughout the product life cycle and the use of preventive development strategies to minimize the negative impact on the natural and social environment. Agenda 21 [26] calls for directing the activities of enterprises to implement cleaner production and responsible entrepreneurship strategies that minimize pressure on the environment, improve resource efficiency and reduce risks and hazards in the economic, environmental and social domains. Referring to Agenda 21 [26], the final document of the RIO+20 Earth Summit, "The Future We Want" [27], emphasizes even more strongly the importance and necessity of introducing corporate social responsibility practices, promoted, among others, by the United Nations Global Compact (par. 46) and encourages reporting of socially responsible activities (par. 47) (2012). Thus, it can be concluded that CSR is an integral tool for implementing the assumptions of sustainable development, and the Global Compact is a supporting program, setting standards for corporate actions based on universal principles $[23,28]$.

The SCOPUS database for the query sustainable AND development AND water AND sewage displays 1931 records, as shown in Figure 2. 


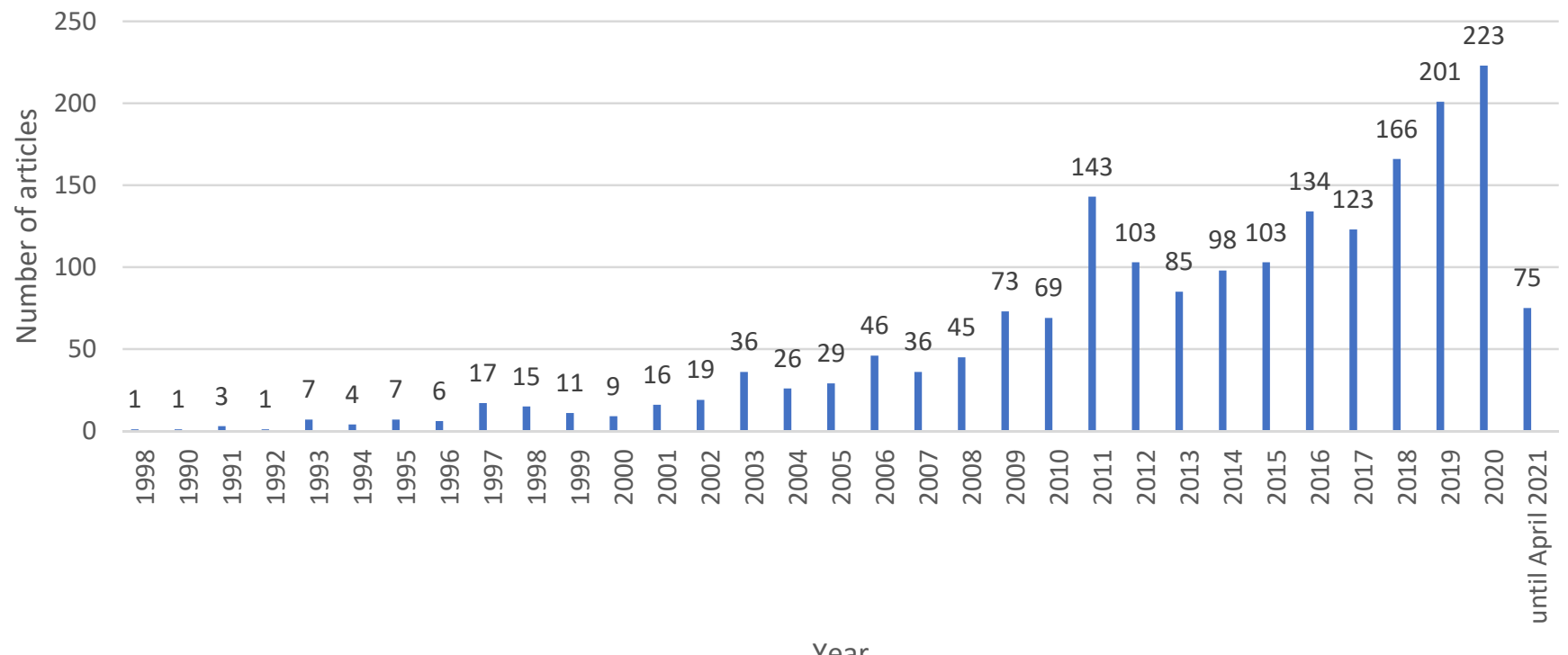

Figure 2. Publications in the SCOPUS database for the query sustainable AND development AND water AND sewage. Source: Own study based on data from Scopus database (accessed on 1 April 2021).

Only 48 results were found for the query sustainable AND development AND water AND sewage AND company. On the other hand, the query corporate AND social AND responsibility AND sustainable AND development AND water AND sewage AND company no longer displays any records.

The interest in corporate social responsibility has been growing over the years, not only among researchers but also among entrepreneurs themselves. However, the motivations of companies to take into account CSR were often only of PR character. Nevertheless, this interest became a source of inspiration to institutionalize CSR. For example, in 2001, the European Commission issued a Green Paper: "Promoting Framework for Corporate Social Responsibility", in which CSR was defined as voluntary social and environmental commitments. Although not obligatory, the European Commission recommended the inclusion of the CSR concept in the business strategy of enterprises [29]. In this view, CSR became not a cost but an investment for the future. A new approach to CSR appeared in the "Renewed EU Strategy 2011-2014", according to which companies are responsible for their impact on society [30]. In 2010, the ISO 26000 standard "Guidance On Social Responsibility" was published [31]. Despite the fact that ISO 26000 does not contain standardized certification regulations, it is not a management system standard and organizations cannot apply for certification, the standard is a tool to support sustainable and socially responsible actions of enterprises and defines key areas of social responsibility, such as organizational governance, human rights, human resources management, environment, fair business practices, consumer issues, community involvement and development [31].

The examples of CSR institutionalization given are only an exemplification of the huge number of documents and solutions supporting, guiding and verifying CSR activities. In the water and sewage industry, the use of existing tools is not fully satisfactory, as shown by the cited study by Lulewicz-Sas and Godlewska [24]. There are also few scientific studies on social responsibility of water and sewage companies. In this respect, the present article fills this gap. The research designed to verify the hypothesis that external stakeholders of PWIK Rybnik positively assess the company's involvement in tasks carried out under corporate social responsibility, notice the involvement in educational activities and additional initiatives of PWIK, improving the quality of life of residents, indicate a new aspect of the company's social involvement based on building relationships with stakeholders, in order to better understand their needs, preferences and satisfaction with the services provided. 
On the other hand, in the context of stakeholder theory, there are 5728 studies on CSR in the SCOPUS database. However, for the query stakeholder AND corporate AND social AND responsibility AND water AND sewage AND company, as well as for the query stakeholder AND corporate AND social AND responsibility AND water AND sewage, there are no records in the database. On the other hand, there are only 62 results for the query stakeholder AND corporate AND social AND responsibility AND water.

Rational water management is important for different stakeholder groups, both people and companies in different sectors, e.g., food [32], mining [33,34], metallurgy [35], hydropower companies [36], tourism companies [37] and agriculture [34]. Rational water management becomes particularly important in social enterprises, which include water and sewage enterprises [38]. The issues of corporate social responsibility and stakeholder value are also addressed in the context of a closed loop economy [39]. The issues of rational use of water resources in the context of closed loop economy are studied from different perspectives, which is also related to the implementation of sustainable development goals. Practical solutions in this area are successfully applied in agriculture, but the use of recycled water for human consumption raises many controversies. The level of acceptance of using such water for body washing, laundry and cleaning is somewhat higher and depends on the level of environmental awareness [40]. Technologies of water purification and recycled material recovery are being successively developed and implemented [10,41-50] to make possible reuse or noninvasive discharge into the environment. The focus of contemporary research also shows the possibility of using cognitive technologies and artificial intelligence in monitoring and designing production processes in enterprises [51,52], which could also be applied to the water and sewage industry. Despite these efforts, the degree of pollution of groundwater and watercourses is still very high. Therefore, there is a need for continuous environmental education and raising the environmental awareness of societies and managers, on whom the direction of enterprise development and the ecological orientation of its activities largely depends. The cited studies on circular economy do not, however, refer directly to the issues of corporate social responsibility, although indirectly the use of closed loop economy tools contributes to the implementation of tasks within the scope of this idea, in particular in the area of environmental protection. There is a need for more intensive involvement of enterprises in environmental education carried out as part of CSR tasks, which is very effectively performed by the studied entity. The hypothesis assumed in the study was that the external stakeholders of PWIK Rybnik positively assess the company's involvement in the tasks carried out as part of corporate social responsibility; they notice the involvement in educational activities and additional initiatives of PWIK that improve the quality of life of its inhabitants.

\section{Materials and Methods}

The research problem was the perception and expectations of stakeholders toward PWiK Rybnik's prosocial activities. Sewage and Water Supply in Rybnik is one of the most modern companies providing services in the scope of water supply and sewage disposal in Poland. The company with long traditions, which has operated since 1967 as a state-owned enterprise and since 2000 as a commercial law company, in its area of activity, i.e., in the City of Rybnik, Jejkowice and Gaszowice Municipalities, provides services for over 26,000 recipients (residential buildings, industrial plants and institutions). The water supply system of the Town of Rybnik and the Municipalities of Jejkowice and Gaszowice is based on four sources: Górnośląskie Przedsiębiorstwo Wodociagów S.A. in Katowice, Stacja Uzdatniania Wody Rybnik-Stodoły, Stacja Uzdatniania Wody Rybnik-Boguszowice, Rajska Street (own water intake), Studnia głębinowa na ul. Tęczowej in Rybnik (own water intake). The length of the water supply network operated in the Municipalities of Rybnik, Gaszowice and Jejkowice is currently $1168 \mathrm{~km}$. On the other hand, the length of the sewage system is $864.02 \mathrm{~km}$. Annually, the Rybnik waterworks provide customers with $5,470,783 \mathrm{~m}^{3}$ of water and treat over $4,700,000 \mathrm{~m}^{3}$ of sewage. The company has been repeatedly awarded and appreciated in national programs, competitions and rankings, 
such as the FAIR PLAY Enterprise Program, Solidna Firma, Gepardy Biznesu, Innosilesia, Solidny Pracodawca and many others.

PWiK Rybnik currently complies with the provisions of the Act on providing information in accordance with the Act on Access to Public Information [53], which states that "any information on public matters constitutes public information within the meaning of the Act and is subject to access under the rules and in the procedure set out in this Act". Therefore, it can be assumed that this is the fulfillment of the requirements of the EU Directive 95/2014 [54] and it is applied to some extent. The company, as a beneficiary of the loan for the expansion of the sewerage network financed from the European Bank for Reconstruction and Development (EBRD), was obliged to prepare certain environmental reports required by the EBRD's internal procedures. The environmental reports are therefore prepared by PWiK Rybnik in accordance with legal requirements.

Additionally, PWiK Rybnik prepares every year a report of the Management Board for its shareholders for the given financial year on its activities, and this report includes all partial reports on its CSR and sustainable development activities. This information is publicly available.

On an ongoing basis, the company consults and agrees with its stakeholders on the impact of its business on the social and economic environment, in particular on the environment and compliance with the Water Framework Directive and EU Directive 91/271/EEC [55]. The evaluation matrix of economic and social factors is formulated in a simplified way, but it is consistent with this type of activity. However, environmental indicators are monitored in great detail and periodical analyses of their parameters are prepared, e.g., through audits.

The issue of water management is directly related to energy. Water supply and sewage treatment are not only the simple act of satisfying customers' expectations, but also, and especially at the sewage treatment plant, a source of renewable energy. If there were no water, there would be no sewage and thus no raw material for energy recovery in various forms. The sewage is a carrier of biogas, which is the raw material for the cogeneration unit to produce electricity, which makes the sewage treatment plant to some extent self-sufficient in energy and producing electricity and heat from its raw material, which leaves no carbon footprint and is in line with the principles of the circular economy. Such a solution is an important element of CSR strategy and sustainable development of the company.

The hypothesis assumed in the study was that the external stakeholders of PWIK Rybnik positively assess the company's involvement in the tasks carried out as part of corporate social responsibility; they notice the involvement in educational activities and additional initiatives of PWIK that improve the quality of life of its inhabitants.

For the purposes of this study, we decided to use a quantitative method-a diagnostic survey. The purpose of such studies is to generalize data from the sample to the entire population, so that conclusions can be drawn about certain characteristics, attitudes or behaviors of the population [56]. The advantages of the survey method are related to the cost-effectiveness of the project and, above all, to the possibility of quick navigation through the data sets [57]. Possible difficulties may be associated with reaching the respondents and achieving a minimum sample size. This problem did not arise in the presented study.

The study used the proprietary questionnaire "Customer opinion research on the activities undertaken by PWiK Rybnik" (Table A1). This tool allowed examination of the opinions and expectations of customers using the services of PWiK Rybnik regarding the CSR activities undertaken by this company. This tool consisted of three parts: the quality of life and needs of residents, the company's image and evaluation of prosocial activities and particulars containing a total of 40 survey questions, addressing a number of issues regarding the use of water provided by PWiK Rybnik by the respondents and opinions on the company's operation. The questions posed in the questionnaire referred to the results of surveys and interviews conducted with stakeholders in 2018 [58-60]. The survey was conducted via the Interankiety.pl Internet platform from 25 September to 31 October 2020. 
The inhabitants of Rybnik and the surrounding towns, using the services of PWiK Rybnik, were asked to participate in the study.

The first step in the analysis was recoding the database and organizing it (including systematizing the respondents' open answers). Then, the normality of the distribution of quotient data was verified using the Shapiro-Wilk test. On this basis, it was possible to select tests and statistical methods to verify the selected relationships.

Statistical calculations were performed using Pearson's $\chi^{2}$ test (with Pearson's coefficient as a measure of the strength of the association), Mann-Whitney U test (with Glass rank biserial correlation coefficient as a measure of effect size), Kruskal-Wallis test, and post hoc test based on multiple comparisons (with epsilon-square coefficient as a measure of effect size) and Spearman's rank order correlation. The significance level of the obtained results was $p<0.05$. Calculations were performed using Statistica v.13.3 PL statistical package from StatSoft, Inc., Tulsa, OK, USA.

The sample selection was random; 1269 residents of Rybnik and surrounding towns participated in the study, including 566 women (Mage $=47.34$; SDage $=48.56$ ) and 703 men (Mage $=48.04 ;$ SDage $=49.18)$. Table 1 shows the exact distribution of men and women by age group.

Table 1. Respondents by gender and age.

\begin{tabular}{|c|c|c|c|c|c|}
\hline & & \multicolumn{4}{|c|}{ Gender } \\
\hline & & \multicolumn{2}{|c|}{$\begin{array}{c}\text { Women } \\
(n=566)\end{array}$} & \multicolumn{2}{|c|}{$\begin{array}{c}\text { Men } \\
(n=703)\end{array}$} \\
\hline & & $n$ & $\%$ & $n$ & $\%$ \\
\hline \multirow{5}{*}{ Age } & Up to 24 years & 4 & $0.71 \%$ & 1 & $0.14 \%$ \\
\hline & 25-34 years & 72 & $12.72 \%$ & 80 & $11.38 \%$ \\
\hline & 35-44 years & 156 & $27.56 \%$ & 193 & $27.45 \%$ \\
\hline & $45-54$ years & 145 & $25.62 \%$ & 176 & $25.04 \%$ \\
\hline & 55 years and over & 189 & $33.39 \%$ & 253 & $35.99 \%$ \\
\hline
\end{tabular}

The minimum sample size was estimated using the sample size formula for qualitative characteristics (with a finite sample):

$$
n=\frac{p(p-1)}{\frac{E^{2}}{t_{\alpha}^{2}}+\frac{p(p-1)}{N}}
$$

where:

$p$-the size of the estimated fraction having the distinguished characteristic;

$E$-permissible maximum estimation error of the ratio p;

$N$-general population size;

$t_{\alpha}$-number of standard deviations to be read from the normal distribution table for a confidence level of $1-\alpha$ [61].

When calculating the minimum sample size, the size of the general population of 138,098 total inhabitants of the administrative district of the city of Rybnik [62], of which $50 \%$ used the services of PWiK Rybnik, was assumed. Moreover, this estimation assumed the $95 \%$ probability that the result obtained in the study will not deviate from the actual value in the population by more than $5 \%$. The minimum sample size estimated in this way was 385 . Thus, the number of respondents $(N=1269)$ achieved exceeded the minimum sample size several times, which made it possible to obtain reliable data in this study. 


\section{Results and Discussion}

PWiK Rybnik, as part of a prosocial initiative, installed in the city of Rybnik water dispensers to quench thirst, especially on hot days. Respondents mostly never used the water dispensers set up in the city as part of the "Reach for Refreshment" campaign, but they still rated the initiative positively $(31.13 \%$ rated it as very necessary and $40.03 \%$ rated it as sometimes useful). Similarly, the water curtains operating during hot weather in Rybnik were rated positively ( $30.58 \%$ as very useful and $41.06 \%$ as fairly useful). As shown by the Mann-Whitney $U$ test, the gender of the respondents statistically significantly differentiated their evaluation of the initiative to sell water in a water dispenser $(Z=5.65 ; p<0.001$; $\mathrm{rg}=0.18)$. Results showed that women rated this initiative better (MrankWomen $=699.81$ ) than men (MrankMen $=582.82$ ). The percentage rating this initiative as sometimes useful and very necessary was higher among women $(42.05 \%$ and $37.81 \%$, respectively) than among men (38.41\% and $25.75 \%$, respectively). On the other hand, the evaluation of the initiative as rather unnecessary (respectively, $23.33 \%$ and $10.42 \%$ ) and not used by anyone (respectively, $12.52 \%$ and $9.72 \%$ ) was more frequent among men than among women. Relationships are presented in Table 2.

Table 2. The relationship between the gender of the respondents and their assessment of the initiative to sell water in a water dispenser.

\begin{tabular}{|c|c|c|c|c|c|c|c|}
\hline & & \multicolumn{4}{|c|}{ Gender } & \multirow{3}{*}{$\begin{array}{c}\text { Mann-Whitney } \\
\text { U Test }\end{array}$} & \multirow{3}{*}{ rg of Glass } \\
\hline & & \multicolumn{2}{|c|}{$\begin{array}{l}\text { Women } \\
(n=566)\end{array}$} & \multicolumn{2}{|c|}{$\begin{array}{c}\text { Men } \\
(n=703)\end{array}$} & & \\
\hline & & $n$ & $\%$ & $n$ & $\%$ & & \\
\hline \multirow{4}{*}{$\begin{array}{l}\text { Evaluation of the } \\
\text { initiative to sell } \\
\text { water in a water } \\
\text { dispenser }\end{array}$} & Nobody uses a water dispenser & 55 & $9.72 \%$ & 88 & $12.52 \%$ & \multirow{4}{*}{$\begin{array}{l}Z=5.65 \\
p<0.001\end{array}$} & \multirow{4}{*}{0.18} \\
\hline & Rather unnecessary & 59 & $10.42 \%$ & 164 & $23.33 \%$ & & \\
\hline & Sometimes useful & 238 & $42.05 \%$ & 270 & $38.41 \%$ & & \\
\hline & Very necessary & 214 & $37.81 \%$ & 181 & $25.75 \%$ & & \\
\hline
\end{tabular}

On the other hand, the age of the respondents was not significant in their evaluation of the initiative to sell water through water dispensers. Respondents from each age group were most likely to have a positive opinion of the initiative and most people considered it sometimes useful (from $36.76 \%$ in the $45-54$ age group to $42.41 \%$ in the $35-44$ age group) or very useful (from $28.65 \%$ in the $35-44$ age group to $36.76 \%$ in the $45-54$ age group). Analysis by Spearman rank order correlation method showed that there was no statistically significant relationship between the abovementioned variables $(\mathrm{R}=-0.02 ; \mathrm{t}(\mathrm{N}-2)=-0.64$; $p=0.523$.

Water conservation is one of the important elements of a closed loop economy strategy. In relation to this, PWiK Rybnik tries to encourage its stakeholders to such actions by means of numerous promotional campaigns in the local media. The survey carried out shows that the vast majority of the respondents $(81.09 \%)$ declared that they save water, mainly by using rainwater $(30.42 \%)$ and taking a shower instead of a bath $(18.76 \%)$ (other methods were indicated by $42.18 \%$ of the respondents). Furthermore, the respondents mostly did not fill the swimming pool in the garden with water $(65.80 \%)$ and also did not use municipal water to water the garden (58.87\%). Additionally, the customers surveyed mostly (42.55\%) used tap water directly for drinking without boiling. Expectations for changes in water distribution management were in many cases dependent on the attitude of the respondents towards water conservation. Although the vast majority of the respondents, regardless of water conservation, had no other expectations, the proportion of such cases was lower in the group of water savers $(80.47 \%)$ compared to those who did not save water $(87.50 \%)$. This difference was found to be statistically significant as shown by analysis with Pearson's $\chi^{2}$ test $\left(\chi^{2}(1)=6.47 ; p<0.05 ; C=0.071\right)$. Thus, from the results, it can be concluded that 
water conservation was associated with perceiving more necessary changes in distribution management. The relationships are presented in Table 3.

Table 3. The relationship between respondents' water conservation and their expectations of changes in water distribution management.

\begin{tabular}{|c|c|c|c|c|c|c|c|}
\hline \multirow{3}{*}{$\begin{array}{c}\text { Expectations for Change } \\
\text { in Water Distribution Managemen }\end{array}$} & & \multicolumn{4}{|c|}{ Water Conservation } & \multirow{3}{*}{ Test $\chi^{2}$} & \multirow{3}{*}{$\begin{array}{l}\text { Contingency } \\
\text { Coefficient }\end{array}$} \\
\hline & & \multicolumn{2}{|c|}{ Yes $(n=1029)$} & \multicolumn{2}{|c|}{ No $(n=240)$} & & \\
\hline & & $n$ & $\%$ & $n$ & $\%$ & & \\
\hline \multirow{2}{*}{ Improvement of water quality } & Yes & 514 & $49.95 \%$ & 114 & $47.50 \%$ & \multirow{2}{*}{$\begin{array}{l}\chi^{2}(1)=0.47 \\
p=0.494\end{array}$} & \multirow{2}{*}{0.019} \\
\hline & No & 515 & $50.05 \%$ & 126 & $52.50 \%$ & & \\
\hline \multirow{2}{*}{$\begin{array}{l}\text { Ability to share information about the } \\
\text { system for improvement }\end{array}$} & Yes & 253 & $24.59 \%$ & 56 & $23.33 \%$ & \multirow{2}{*}{$\begin{array}{c}\chi^{2}(1)=0.17 \\
p=0.684\end{array}$} & \multirow{2}{*}{0.011} \\
\hline & No & 776 & $75.41 \%$ & 184 & $76.67 \%$ & & \\
\hline \multirow{2}{*}{$\begin{array}{l}\text { Reduce the number of failures in the } \\
\text { water supply system }\end{array}$} & Yes & 172 & $16.72 \%$ & 44 & $18.33 \%$ & \multirow{2}{*}{$\begin{array}{c}\chi^{2}(1)=0.36 \\
p=0.548\end{array}$} & \multirow{2}{*}{0.017} \\
\hline & No & 857 & $83.28 \%$ & 196 & $81.67 \%$ & & \\
\hline \multirow{2}{*}{ Improved communication with the utility } & Yes & 181 & $17.59 \%$ & 55 & $22.92 \%$ & \multirow{2}{*}{$\begin{array}{c}\chi^{2}(1)=3.65 \\
p<0.056\end{array}$} & \multirow{2}{*}{0.054} \\
\hline & No & 848 & $82.41 \%$ & 185 & $77.08 \%$ & & \\
\hline \multirow{2}{*}{ Other } & Yes & 201 & $19.53 \%$ & 30 & $12.50 \%$ & \multirow{2}{*}{$\begin{array}{l}\chi^{2}(1)=6.47 \\
p<0.05\end{array}$} & \multirow{2}{*}{0.071} \\
\hline & No & 828 & $80.47 \%$ & 210 & $87.50 \%$ & & \\
\hline
\end{tabular}

The use of tap water directly for drinking is another important behavior related to the strategy of the closed cycle economy. Apart from purely material benefits, it is connected with the cleanliness of the natural environment, which is struggling with the problem of processing the surplus of PET bottles after mineral water. Increasing such environmental awareness of stakeholders is also one of the elements of PWiK Rybnik campaign. The conducted research indicated that using tap water directly for drinking without boiling did not depend on the gender of the respondents. Both women and men mostly used tap water in the abovementioned way and the percentage of such cases was very similar in both groups ( $42.58 \%$ and $42.53 \%$ respectively). The percentages of drinking tap water only after boiling and buying bottled water were also similarly distributed in both groups. Pearson's $\chi^{2}$ test analysis showed that there were no statistically significant differences between men and women in terms of using tap water directly for drinking without boiling $\left(\chi^{2}(2)=0.05\right.$; $p=0.978 ; C=0.006$ ). Water conservation also did not depend on the gender of the subjects. The vast majority of respondents, both female and male, declared saving water $(81.27 \%$ and $80.94 \%$, respectively). There were no statistically significant differences between the two groups in this respect, as shown by Pearson's $\chi^{2}$ test analysis $\left(\chi^{2}(1)=0.02 ; p=0.88\right)$.

Analysis by Kruskal-Wallis test showed that the age of the respondents was statistically significantly different between the groups distinguished by the use of tap water directly for drinking without boiling $\left(\mathrm{H}(2, \mathrm{~N}=1269)=10.01 ; p<0.01 ; E_{R}^{2}=0.01\right)$. On the other hand, post hoc test showed that subjects drinking tap water directly without boiling were significantly younger than those drinking such water only after prior boiling $(p<0.01)$. Further analysis of the results obtained allowed us to conclude that people aged at least 55 years drank tap water directly for drinking without boiling less frequently $(35.97 \%)$ than younger people (from $43.95 \%$ in the age group up to 34 years to $47.56 \%$ in the age group 35-44 years). At the same time, those in the oldest age group drank tap water more often only after prior boiling (31.90\%) compared to younger groups (from $22.29 \%$ in the age group up to 34 years to $25.79 \%$ in the age group $35-44$ years).

Moreover, the age of the respondents was significant to their lifestyle in terms of water conservation. It was found that water savers were older (MrankYes $=658.54)$ compared to those who did not save water $(\mathrm{MrankNo}=534.06)$. Although most of the respondents from each age group were water savers, the percentage of water savers was lower among those 
aged up to 45 (71.34\% in the group up to 34 years and $74.79 \%$ in the group $35-44$ years, respectively) than among those older than they $(86.29 \%$ in the group $45-54$ years and $85.75 \%$ in the group 55 years and above, respectively). These differences were statistically significant, as demonstrated by the Mann-Whitney $U$ test $(Z=4.74 ; p<0.001 ; \mathrm{rg}=0.20)$.

The website of PWiK Rybnik was visited regularly by the majority of respondents (58.63\%), mainly to get familiar with the current announcements (54.84\%) and to obtain information from the Customer Service Office for contact purposes (38.44\%). In case of malfunctions, the respondents mostly used (65.80\%) the telephone method of reporting. On the other hand, e-mail was the most appropriate contact type for respondents to receive information related to personal water use (71.55\%).

The following were most frequently cited by respondents as the most interesting information related to personal water use: water supply interruptions $(74.39 \%)$, emergencies $(52.32 \%)$, current water chemical parameters $(49.57 \%)$, alarms for improper water flows in the customer's home (46.26\%) and characteristics of personal water use (41.37\%). More than half of the respondents (51.69\%) expressed willingness to provide information on planned high water use. Willingness to provide information on planned high water consumption differed significantly between men and women. Admittedly, the majority of the respondents in both groups expressed the abovementioned readiness and additionally the percentage of such cases in both groups was very similar $(51.59 \%$ and $51.78 \%$ respectively). However, among men the lack of readiness to provide the abovementioned information was more frequent $(18.35 \%)$ than among women $(13.43 \%)$, who in turn more often did not have a definite opinion about the readiness $(34.98 \%)$ compared to men $(39.87 \%)$. These differences were statistically significant, as shown by analysis with Pearson's $\chi^{2}$ test $\left(\chi^{2}(2)=7.25 ; p<0.05 ; C=0.075\right)$. Analysis by the Kruskal-Wallis test showed that the age of the subjects was statistically significantly different between the groups distinguished by their willingness to provide information on planned high water consumption $\left(\mathrm{H}(2, \mathrm{~N}=1269)=16.54 ; p<0.001 ; E_{R}^{2}=0.01\right)$. On the other hand, a post hoc test showed that those expressing the aforementioned readiness were significantly younger than those with no specific opinion on this issue $(p<0.001)$. As can be read from the results of the percentage distribution, the older the respondents were, the smaller percentage of them declared readiness to provide the abovementioned information (from $63.06 \%$ in the age group up to 34 years to $47.06 \%$ in the age group of 55 and more years) and, at the same time, the greater was the percentage of respondents who did not have an established knowledge of the abovementioned readiness (respectively, from $20.38 \%$ to $36.65 \%$ ).

The willingness of the respondents to provide information about the planned high water consumption had an impact on some expectations about water parameters in relation to water quality improvement. Those who did not express the abovementioned readiness were more likely to expect improvement in taste (59.05\%) and smell of water (36.19\%) compared to the groups of respondents willing to provide the abovementioned information $(41.50 \%$ and $25.82 \%$, respectively) and those who did not have a specific opinion on this readiness ( $40.55 \%$ and $22.12 \%$, respectively). The differences between the abovementioned groups were statistically significant, which was shown by the Pearson's $\chi^{2}$ test, both in relation to the taste parameter $\left(\chi^{2}(2)=11.46 ; p<0.01 ; C=0.134\right)$ and smell $\left(\chi^{2}(2)=7.3\right.$; $p<0.05 ; C=0.107)$. The detailed relations are presented in Table 4.

On the other hand, expectations of improved water in terms of hardness and purity did not depend on the willingness of the respondents to provide information on the planned high water consumption. The majority of respondents, regardless of the abovementioned readiness, expected improvement in water purity (from $58.50 \%$ in the group of persons ready to provide the abovementioned information to $65.71 \%$ in the group of those not ready to provide such information) and, at the same time, had no expectations concerning improvement in water hardness (from $50.48 \%$ in the group of persons not ready to provide the abovementioned information to $51.63 \%$ in the group of persons ready to provide the abovementioned information). As shown by Pearson's $\chi^{2}$ test analysis, there were no statistically significant differences between the aforementioned groups, both in terms of 
expectation of water hardness improvement $\left(\chi^{2}(2)=0.04 ; p=0.978 ; C=0.008\right)$ and its purity $\left(\chi^{2}(2)=2.35 ; p=0.308 ; C=0.061\right)$.

Table 4. Relationship between respondents' willingness to provide information about planned high water use and their expectations about water parameters in relation to water quality improvement.

\begin{tabular}{|c|c|c|c|c|c|c|c|c|c|}
\hline \multirow{3}{*}{\multicolumn{2}{|c|}{$\begin{array}{l}\text { Expectations for Water } \\
\text { Parameters in Relation to } \\
\text { Improving Water Quality }\end{array}$}} & \multicolumn{6}{|c|}{$\begin{array}{l}\text { Readiness to Provide Information } \\
\text { on Planned High Water Use }\end{array}$} & \multirow{3}{*}{ Test $\chi^{2}$} & \multirow{3}{*}{$\begin{array}{l}\text { Contingency } \\
\text { Coefficient }\end{array}$} \\
\hline & & \multicolumn{2}{|c|}{$\begin{array}{c}\text { Yes } \\
(n=306)\end{array}$} & \multicolumn{2}{|c|}{$\begin{array}{c}\text { No } \\
(n=105)\end{array}$} & \multicolumn{2}{|c|}{$\begin{array}{l}\text { I Do Not Know } \\
\quad(n=217)\end{array}$} & & \\
\hline & & $n$ & $\%$ & $n$ & $\%$ & $n$ & $\%$ & & \\
\hline \multirow{2}{*}{ Hardness } & Yes & 148 & $48.37 \%$ & 52 & $49.52 \%$ & 106 & $48.85 \%$ & \multirow{2}{*}{$\begin{array}{c}\chi^{2}(2)=0.04 \\
p=0.978\end{array}$} & \multirow{2}{*}{0.008} \\
\hline & No & 158 & $51.63 \%$ & 53 & $50.48 \%$ & 111 & $51.15 \%$ & & \\
\hline \multirow{2}{*}{ Taste } & Yes & 127 & $41.50 \%$ & 62 & $59.05 \%$ & 88 & $40.55 \%$ & \multirow{2}{*}{$\begin{array}{l}\chi^{2}(2)=11.46 \\
\quad p<0.01\end{array}$} & \multirow{2}{*}{0.134} \\
\hline & No & 179 & $58.50 \%$ & 43 & $40.95 \%$ & 129 & $59.45 \%$ & & \\
\hline \multirow{2}{*}{ Smell } & Yes & 79 & $25.82 \%$ & 38 & $36.19 \%$ & 48 & $22.12 \%$ & \multirow{2}{*}{$\begin{array}{l}\chi^{2}(2)=7.3 \\
p<0.05\end{array}$} & \multirow{2}{*}{0.107} \\
\hline & No & 227 & $74.18 \%$ & 67 & $63.81 \%$ & 169 & $77.88 \%$ & & \\
\hline \multirow{2}{*}{ Purity } & Yes & 179 & $58.50 \%$ & 69 & $65.71 \%$ & 138 & $63.59 \%$ & \multirow{2}{*}{$\begin{array}{l}\chi^{2}(2)=2.35 \\
p=0.308\end{array}$} & \multirow{2}{*}{0.061} \\
\hline & No & 127 & $41.50 \%$ & 36 & $34.29 \%$ & 79 & $36.41 \%$ & & \\
\hline
\end{tabular}

In terms of expectations of change in water distribution management, it was found that nearly half of the respondents (49.49\%) expected improvement in water quality, with the majority having concerns about purity (61.46\%). In addition, a significant proportion of respondents expected improvement in water quality in terms of hardness $(48.73 \%)$ and taste $(44.11 \%)$. Almost one in four respondents $(24.35 \%)$ expected a change in the management of water distribution in terms of being able to share information about the system in order to continuously improve it. Some of the expectations for water parameters in relation to improving water quality were related to the number of people in the respondents household. Respondents who expected improvement in terms of water hardness and taste lived in a household with more people $(\mathrm{M}=3.74 ; \mathrm{SD}=2.32$ and $\mathrm{M}=3.71 ; \mathrm{SD}=1.99$, respectively) compared to respondents without these expectations $(\mathrm{M}=3.34 ; \mathrm{SD}=1.51$ and $\mathrm{M}=3.4 ; \mathrm{SD}=1.92$, respectively). These differences proved to be statistically significant, as shown by analysis with the Mann-Whitney $U$ test, both for water hardness $(Z=2.34$; $p<0.05 ; \mathrm{rg}=0.11)$ and its taste $(Z=2.53 ; p<0.05 ; \mathrm{rg}=0.12)$. The remaining expectations regarding water parameters in relation to the improvement of its quality did not depend on the number of people in the household. As in the case of hardness and taste, respondents expecting improvement in terms of smell and purity lived in a household with more people $(\mathrm{M}=3.72 ; \mathrm{SD}=2.19$ and $\mathrm{M}=3.53 ; \mathrm{SD}=2.16$, respectively) than respondents without such expectations $(\mathrm{M}=3.47 ; \mathrm{SD}=1.86$ and $\mathrm{M}=3.53 ; \mathrm{SD}=1.59$, respectively). However, as shown by the Mann-Whitney $U$ test analysis, the number of people in the household was not statistically significantly different between the groups distinguished in terms of the aforementioned expectations, i.e., regarding smell $(Z=1.43 ; p=0.152 ; \mathrm{rg}=0.08)$ and purity $(\mathrm{Z}=-0.74 ; p=0.459 ; \mathrm{rg}=-0.04)$. Detailed relationships are presented in Table 5.

On the other hand, the operation of the sewage treatment plant in the city and the sewage pumping station did not lead to negative effects in the majority of the inhabitants surveyed $(71.63 \%$ and $89.20 \%$, respectively). Among those who assessed the functioning of the abovementioned sewage treatment plant, almost all (99.21\%) indicated smell as a nuisance factor. 
Table 5. Relationship between the number of people in the respondents' household and their expectations of water parameters in relation to water quality improvement.

\begin{tabular}{|c|c|c|c|c|c|c|c|c|c|}
\hline \multirow{3}{*}{\multicolumn{2}{|c|}{$\begin{array}{l}\text { Expectations for Water } \\
\text { Parameters in Relation to } \\
\text { Improving Water Quality }\end{array}$}} & \multicolumn{6}{|c|}{ Descriptive Statistics-Number of Persons in Household } & \multirow{3}{*}{$\begin{array}{l}\text { U Mann- } \\
\text { Whitney } \\
\text { Test }\end{array}$} & \multirow{3}{*}{$\begin{array}{l}\text { rg of } \\
\text { Glass }\end{array}$} \\
\hline & & \multirow{2}{*}{$\begin{array}{l}\text { Mean } \pm \\
\text { standard } \\
\text { Deviation. }\end{array}$} & \multirow{2}{*}{$\begin{array}{l}\text { Median } \\
\text { (Q25-Q75) }\end{array}$} & \multirow{2}{*}{ Min.-Maks. } & \multicolumn{2}{|c|}{$\begin{array}{l}\text { Confidence } \\
\text { Interval }\end{array}$} & \multirow{2}{*}{$\begin{array}{l}\text { Standard } \\
\text { Deviation }\end{array}$} & & \\
\hline & & & & & $-95.00 \%$ & $+95.00 \%$ & & & \\
\hline \multirow{2}{*}{ Hardness } & Yes $(n=306)$ & $3.74 \pm 2.32$ & $4(2-5)$ & $1-24$ & 3.48 & 4.00 & 0.13 & \multirow{2}{*}{$\begin{array}{l}Z=2.34 \\
p<0.05\end{array}$} & \multirow{2}{*}{0.11} \\
\hline & No $(n=322)$ & $3.34 \pm 1.51$ & $3(2-4)$ & $1-8$ & 3.17 & 3.50 & 0.08 & & \\
\hline \multirow{2}{*}{ Taste } & Yes $(n=277)$ & $3.71 \pm 1.99$ & $4(2-5)$ & $1-24$ & 3.47 & 3.94 & 0.12 & \multirow{2}{*}{$\begin{array}{l}Z=2.53 \\
p<0.05\end{array}$} & \multirow{2}{*}{0.12} \\
\hline & No $(n=351)$ & $3.4 \pm 1.92$ & $3(2-4)$ & $1-24$ & 3.20 & 3.60 & 0.10 & & \\
\hline \multirow{2}{*}{ Smell } & Yes $(n=165)$ & $3.72 \pm 2.19$ & $3(2-5)$ & $1-24$ & 3.38 & 4.05 & 0.17 & \multirow{2}{*}{$\begin{array}{l}Z=1.43 \\
p=0.152\end{array}$} & \multirow{2}{*}{0.08} \\
\hline & No $(n=463)$ & $3.47 \pm 1.86$ & $3(2-4)$ & $1-24$ & 3.30 & 3.64 & 0.09 & & \\
\hline \multirow{2}{*}{ Purity } & Yes $(n=386)$ & $3.54 \pm 2.16$ & $3(2-4)$ & $1-24$ & 3.32 & 3.75 & 0.11 & \multirow{2}{*}{$\begin{aligned} \mathrm{Z} & =-0.74 \\
p & =0.459\end{aligned}$} & \multirow{2}{*}{-0.04} \\
\hline & No $(n=242)$ & $3.53 \pm 1.59$ & $3(2-4)$ & $1-14$ & 3.33 & 3.73 & 0.10 & & \\
\hline
\end{tabular}

The vast majority of respondents did not know the individual initiatives organized by PWiK to develop environmental awareness. The logo of PWiK Rybnik was known to the vast majority of respondents (93.54\%), in contrast to the marketing slogans promoting PWiK Rybnik (97.79\% of respondents did not know them). Moreover, the overwhelming majority of respondents did not know the activities to improve the condition of the environment carried out by PWiK Rybnik (98.74\%), and did not have any proposals in this regard (89.44\%).

Most of the respondents (54.77\%) noticed the necessity of cooperation between PWiK Rybnik and scientific and research institutes in order to implement improvements in the company's operation, mainly in order to more effectively treat sewage (37.82\%) and ensure failure-free operation of the water supply network (31.67\%). On the other hand, almost none of the respondents knew the activities of PWiK supporting the development of local organizations (only $0.71 \%$ declared knowledge of the abovementioned activities). The expectations towards PWiK Rybnik in terms of the effects of cooperation with scientific and research institutes depended on the fact whether the respondents had a garden. It turned out that the respondents who had a garden expected the abovementioned effects in the form of failure-free operation of the water supply network $(32.81 \%)$ and reduction of nuisance related to sewage disposal (12.93\%) compared to people without a garden ( $25.27 \%$ and $9.34 \%$, respectively). In the latter group, the percentage of people expecting more effective sewage treatment plants (39.01\%), modern information exchange systems between the company and customers $(19.23 \%)$, and other effects of cooperation with scientific and research institutes $(7.14 \%)$ was higher than in the group of people who own a garden (respectively, 37.61\%, 13.12\% and 3.53\%). The analysis with Pearson's $\chi^{2}$ test showed that the expectations towards the effects of the abovementioned cooperation differed significantly between the groups distinguished due to having a garden $\left(\chi^{2}(4)=13.52\right.$; $p<0.01 ; C=0.105)$. Detailed relationships are presented in Table 6 . 
Table 6. Relationship between the respondents' possession of a garden and their expectations towards PWiK Rybnik in terms of the effects of cooperation with scientific and research institutes.

\begin{tabular}{|c|c|c|c|c|c|c|c|}
\hline & & \multicolumn{4}{|c|}{ Possession of Garden } & \multirow{3}{*}{ Test $\chi^{2}$} & \multirow{3}{*}{$\begin{array}{l}\text { Contingency } \\
\text { Coefficient }\end{array}$} \\
\hline & & \multicolumn{2}{|c|}{$\begin{array}{c}\text { Yes } \\
(n=1021)\end{array}$} & \multicolumn{2}{|c|}{$\begin{array}{c}\text { No } \\
(n=182)\end{array}$} & & \\
\hline & & $n$ & $\%$ & $n$ & $\%$ & & \\
\hline \multirow{5}{*}{$\begin{array}{l}\text { Expectations towards PWiK } \\
\text { Rybnik in terms of effects of } \\
\text { cooperation with scientific } \\
\text { and research institutes }\end{array}$} & $\begin{array}{l}\text { Failure-free operation of } \\
\text { water supply systems }\end{array}$ & 335 & $32.81 \%$ & 46 & $25.27 \%$ & \multirow{5}{*}{$\begin{array}{l}\chi^{2}(4)=13.52 \\
\quad p<0.01\end{array}$} & \multirow{5}{*}{0.105} \\
\hline & $\begin{array}{l}\text { More efficient sewage } \\
\text { treatment plants }\end{array}$ & 384 & $37.61 \%$ & 71 & $39.01 \%$ & & \\
\hline & $\begin{array}{l}\text { Reduction of nuisance related } \\
\text { to sewage disposal }\end{array}$ & 132 & $12.93 \%$ & 17 & $9.34 \%$ & & \\
\hline & $\begin{array}{c}\text { Modern systems of } \\
\text { information exchange } \\
\text { between the company and its } \\
\text { customers }\end{array}$ & 134 & $13.12 \%$ & 35 & $19.23 \%$ & & \\
\hline & Other & 36 & $3.53 \%$ & 13 & $7.14 \%$ & & \\
\hline
\end{tabular}

\section{Conclusions}

Based on the survey, cognitive conclusions were drawn. The surveyed inhabitants of Rybnik and the neighboring localities have used water sparingly. As water conservation is one of the important elements of the closed circuit economy strategy, it can be concluded that numerous promotional campaigns carried out by PWiK in the local media have encouraged the stakeholders to such behavior. The stakeholders implemented savings in this area by using rainwater and taking a shower instead of a bath. In addition, respondents mostly did not fill the swimming pool in the garden with water, nor did they use municipal water to water the garden. Moreover, a significant proportion of the respondents drank water directly from the tap, which also confirms the ecological awareness of the stakeholders (reducing the amount of PET bottles in the environment) that PWiK Rybnik promotes.

Having a nonreturnable water meter by the respondents partially influenced their awareness of their own behavior related to water consumption. Those who owned the device or were planning to buy one were more likely to use municipal water for garden watering and were more likely to fill the swimming pool in the garden with water. Thus, the nonreturnable water meter contributed to a freer use of water. Therefore, it cannot be concluded that having this device influenced greater savings in this area of water use. At the same time, respondents planning to purchase a nonreturnable water meter more often expressed willingness to provide information about their planned high water use, which indicates their greater desire to have knowledge about water use and to share that knowledge.

The expectations of residents of Rybnik and surrounding areas towards PWiK Rybnik varied little depending on the number of residents in their household. People living in larger households (with more people) more often expected improvement in water quality in terms of its hardness and taste. Other expectations, both for changes in water distribution management and cooperation with scientific research institutions, did not depend on the number of people in the household. To a greater extent, having a garden influenced the abovementioned expectations of the respondents. People with a garden were more likely to have their own nonstandard expectations regarding changes in water distribution management, and were more likely to emphasize the need to ensure failure-free operation of the water supply system and to reduce the nuisance associated with sewage disposal as a result of cooperation with the abovementioned institutions.

The initiative to sell water through a dispenser was assessed differently among women and men (women rated the initiative better), while the age of the surveyed inhabitants of 
Rybnik and surrounding towns had no significance for the usefulness of the initiative to sell water through a dispenser.

On the basis of surveys conducted, practical conclusions were drawn that could be a kind of guidelines for prosocial activities for water and sewage companies. The surveyed inhabitants of Rybnik and surrounding localities expected from PWiK Rybnik first of all improvement of water quality (mainly in terms of its purity), as well as cooperation with science and research institutes in order to implement improvements in company operations (mainly in the form of more efficient sewage treatment and ensuring failurefree operation of water supply system). Taking into account these results, the company will take them into account in its investment plans, especially in the typing protocols defining future replacement investments in the Long-Term Plan for Development and Modernization of Water Supply Facilities for the next three years, i.e., 2023-2025. Knowing the priorities and expectations of customers/respondents, the company will increase the level of customer satisfaction with the water supply and wastewater collection services provided. Furthermore, knowing the expectations regarding the irretrievably used water meters, the company will take a legislative initiative to amend the Act on Collective Water Supply to allow the so-called night-price tariff in order to encourage watering gardens at night. The legislative initiative will be consulted on the forum of water supply companies. Cyclical meetings are held several times a year to discuss the problems that should be solved.

The gender of the inhabitants of Rybnik and the surrounding area did not influence their awareness of their own water consumption and water saving behavior. Only the willingness to provide information on planned high water consumption depended on gender (men were more likely to express no readiness, while women were more likely to have no specific opinion on the matter). On the other hand, the age of the respondents influenced their aforementioned awareness; i.e., younger people more often drank tap water directly without boiling and filled the swimming pool in the garden with water, less often saved it, and additionally more often watered the garden in the early evening. In addition, younger people were more likely to be willing to provide information about planned high water use. This means that the group of residents who need to be educated (made aware) about water consumption and water saving are younger people (both women and men), and their willingness to share the abovementioned information may prove the success of such an initiative. Therefore, in line with the sustainable development strategy, the company will intensify its activities aimed at raising the environmental awareness of the society in a specific age bracket by conducting targeted campaigns for specific social groups. The intensification of activities will also involve greater use of remote communication means to promote specific behaviors in water use and wastewater discharge. These campaigns have already been carried out despite the COVID-19 pandemic; however, the results of the research indicate more precisely the direction for future awareness-raising campaigns. PWiK Rybnik, as an active participant of social and economic life, shares the emerging social needs with other water supply companies by openly presenting the acquired knowledge on social expectations in the field of environmental protection, and encourages other water supply companies to similar actions.

Expectations towards PWiK Rybnik depended partly on the respondents' lifestyle in terms of water consumption. Those who did not drink water directly from the tap (without boiling) more often expected improvement in water quality, mainly in terms of its purity. Water savers, on the other hand, were more likely to have their own customized expectations of changes in water distribution management. Moreover, water savers were more likely to expect that the cooperation of PWiK Rybnik with scientific and research institutions would help reduce the nuisance associated with wastewater discharge. In addition, people watering the garden early and late in the evening were more likely to expect improvement in water quality, while the time of day when these activities were carried out was of no importance for the water parameter requiring improvement, according to the expectations of the respondents. Knowing the expectations of this group of 
customers, the company intends to run a second shift of the accredited, in-house analytical laboratory during the spring and summer, using data from the SCADA management system on larger water intakes. The aim of starting the second shift will be more detailed testing of water parameters to meet the customers' expectations.

PWiK Rybnik actively participates in regular workshops of interlaboratory studies and intends to present the expectations of customers resulting from the studies conducted and will propose directing the studies so that they are in line with the expectations of customers and can have practical application in everyday work of other water supply companies in Poland.

The persons ready to provide their information about planned high water consumption had different expectations towards PWiK Rybnik compared to those not ready to do so, i.e., they more often expected changes in water distribution management in the form of possibility to exchange information about the system in order to improve it (readiness to share information was connected with readiness to participate in system improvement) and at the same time less often (together with those not ready to do so) expected improvement of water quality in terms of its taste and smell. In addition, those willing to provide this information more often expected PWiK Rybnik to cooperate with scientific and research institutions, but the effects of such cooperation were not related to the abovementioned readiness. The company is constantly intensifying the cooperation with scientific and research institutions, which is proved by the surveys conducted. All comments and conclusions resulting from this activity are included in the annual report on the standard of service provision by the enterprise and are presented to the supervisory authorities. All remarks which require a longer time horizon are thoroughly analyzed by appointed problem solving teams and the resulting conclusions are taken into account in the update of the company's strategy. The company, having written in its strategy a desire to be an innovation leader in the region, intends to further develop cooperation with scientific and research institutions and intensify the exchange of research experience with other water supply companies, among others, through participation in various types of scientific research.

All CSR activities undertaken by PWiK Rybnik are genuine proecological activities. In its action strategy, the company has included ecological operations aiming at shaping and raising ecological awareness of the society. Therefore, educational campaigns are conducted on a large scale. An environmental education path has also been launched at the sewage treatment plant.

The research results presented are important, especially because of the possibility of their practical use by the water supply and sewage sector. An example of this can be the orientation of information campaigns in the field of environmental protection. It should be noted that for the Polish water and sewage sector, the approach presented in the article is novel and creates a new standard for the future. Stakeholders of PWiK Rybnik perceive very positively the practices carried out by the company, which is also confirmed by the acceptance of these activities at the general meeting of shareholders through approval of the management board reports, which include information about CSR. The company's shareholders are in 100\% local governments, which in their action strategies focus primarily on the development of the idea of corporate social responsibility and respect for the idea of Greendeal as superior values in the field of environmental protection. The actions taken by PWiK Rybnik related to CSR constantly make the community aware of the importance of these ideas for the quality of life of the inhabitants, which was reflected in the survey and confirmed the adopted hypothesis and the company's belief that it should continue on the chosen direction of development.

The article has some limitations. First, it is a case study of one company providing water and sewage services in Poland. Second, the opinions referring to corporate social responsibility practices concern only the water supply and sewage industry. However, taking into account the specificity of this industry, it is difficult to compare it to other types of activities. On the other hand, it is worth considering the possibility of similar surveys in 
other countries, to identify similar and different CSR practices in water supply and sewage companies.

Author Contributions: Conceptualization, A.K., J.O. and J.K.; methodology, A.K., J.O. and J.K.; software, J.O.; validation, A.K., J.O. and J.K.; formal analysis, A.K., J.O. and J.K.; writing-original draft preparation, A.K., J.O. and J.K.; writing-review and editing, A.K., J.O. and J.K.; visualization, A.K., J.O. and J.K.; supervision, A.K., J.O. and J.K. All authors have read and agreed to the published version of the manuscript.

Funding: This research was funded by Department of Applied Social Sciences of the Faculty of Organization and Management of the Silesian University of Technology, grant number 2021: 13/020/BK21/0062.

Institutional Review Board Statement: Not applicable.

Informed Consent Statement: Not applicable.

Conflicts of Interest: The authors declare no conflict of interest.

Appendix A

Box A1. Survey of Customer Opinion on the Actions Taken by PWiK Rybnik. Questionnaire Survey.

\section{Dear Sirs,}

We kindly ask you to fill in the following questionnaire, which aims at getting to know your opinion on the activities undertaken by PWiK Rybnik. The survey is anonymous, personal data will not be used to prepare the report. Research results will contribute to further improvement of services provided by the company and thus to increase the quality of life of Rybnik residents.

Instruction: Please read the following statements carefully and check the selected answer with the cursor. Next to each item you will find detailed instructions on how to respond. In close-ended questions, please choose one answer or all of the true answers if there is a multiple-choice clause, or the indicated number of answers.

Table A1. Questionnaire survey.

\begin{tabular}{|c|c|c|c|}
\hline \multicolumn{4}{|l|}{ I. Quality of Life and Residents' Needs } \\
\hline $\begin{array}{l}\text { 1. Do you use the water dispenser set up in the } \\
\text { city as part of the "Get refreshed" campaign? }\end{array}$ & & $\begin{array}{l}\text { I use it regularly } \\
\text { I use it a lot } \\
\text { I have rarely used it }\end{array}$ & $\begin{array}{l}1 \\
2 \\
3\end{array}$ \\
\hline PLEASE SELECT ONLY ONE ANSWER & O & I have never used & \\
\hline $\begin{array}{l}\text { 2. How do you rate the dispenser water sales } \\
\text { initiative? }\end{array}$ & $\begin{array}{l}\bigcirc \\
0 \\
0\end{array}$ & $\begin{array}{l}\text { It is very necessary, especially in hot weather } \\
\text { Sometimes useful } \\
\text { Rather unnecessary }\end{array}$ & $\begin{array}{l}1 \\
2 \\
3\end{array}$ \\
\hline PLEASE SELECT ONLY ONE ANSWER & 0 & I don't suppose anyone uses a water dispenser & \\
\hline $\begin{array}{l}\text { 3. Do you use tap water directly for drinking, } \\
\text { without boiling? } \\
\text { PLEASE SELECT ONLY ONE ANSWER }\end{array}$ & $\begin{array}{l}\bigcirc \\
\bigcirc \\
0\end{array}$ & $\begin{array}{l}\text { Yes } \\
\text { No, I drink it after boiling it first } \\
\text { No, I buy bottled water }\end{array}$ & $\begin{array}{l}1 \\
2 \\
3\end{array}$ \\
\hline $\begin{array}{l}\text { 4. How do you rate the water curtains operating } \\
\text { during hot weather in Rybnik? } \\
\text { PLEASE SELECT ONLY ONE ANSWER }\end{array}$ & $\begin{array}{l}0 \\
0 \\
0\end{array}$ & $\begin{array}{l}\text { They are very useful, they make city life easier in hot weather } \\
\text { Quite useful, they allow for temporary refreshment } \\
\text { Not useful, they have no influence on my self-esteem during hot } \\
\text { weather } \\
\text { Hard to say }\end{array}$ & $\begin{array}{l}1 \\
2 \\
3 \\
4\end{array}$ \\
\hline
\end{tabular}


Table A1. Cont.

\begin{tabular}{|c|c|}
\hline \multirow{8}{*}{$\begin{array}{l}\text { 5. Do you save water? } \\
\text { PLEASE SELECT ONLY ONE ANSWER }\end{array}$} & $\begin{array}{l}\text { Yes } \\
\text { (how?) }\end{array}$ \\
\hline & 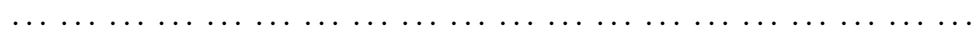 \\
\hline & 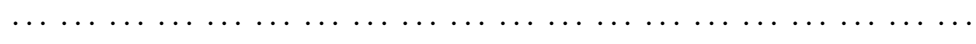 \\
\hline & 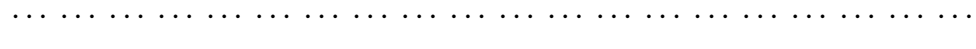 \\
\hline & 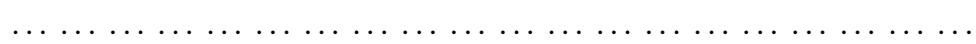 \\
\hline & 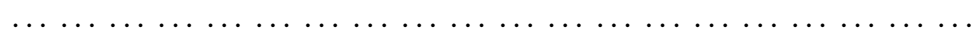 \\
\hline & $\ldots \ldots \ldots \ldots \ldots \ldots \ldots \ldots$ \\
\hline & $\bigcirc \quad$ No, I don't pay attention to that \\
\hline
\end{tabular}

6. Do you fill the garden swimming pool?

$\bigcirc \quad$ Yes

PLEASE SELECT ONLY ONE ANSWER

\section{PLEASESELECT ONLY ONE ANSWER}

○ No

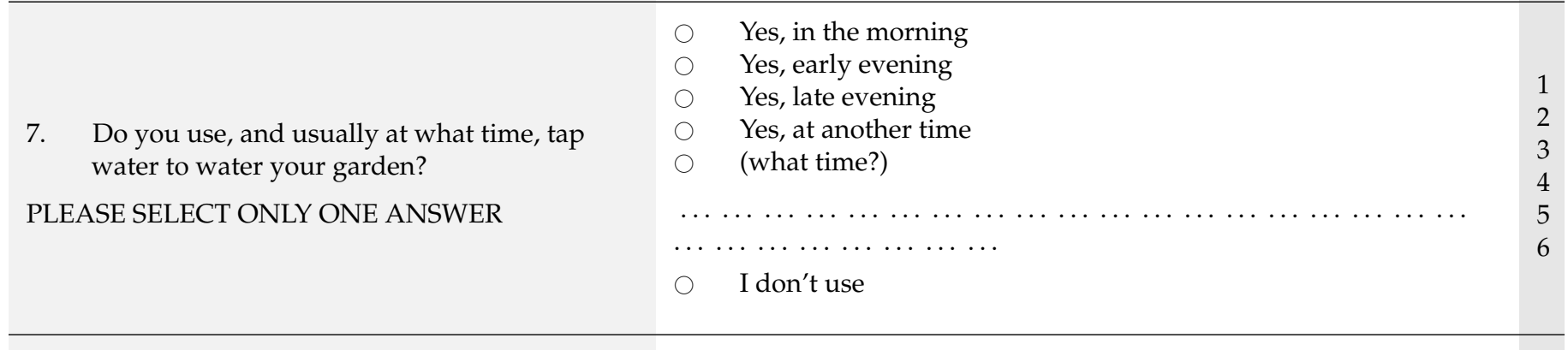

\section{Do you visit the website of PWiK Rybnik? PLEASE SELECT ONLY ONE ANSWER}

9. If yes, which information is read and viewed by you?

Multiple choice

10. How do you communicate with PWiK in case of a network failure?

\section{PLEASE SELECT ONLY ONE ANSWER}

Y Yes

No (please continue to question 13)

- Customer Service information for contact purposes (e.g., opening 1 hours)

○ Current announcements 2

- Company information, organizational structure 3

$\bigcirc \quad$ Information about services offered by the company 4

O Other 5

(specify)

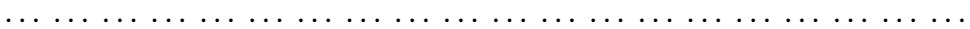

$\ldots \ldots \ldots \ldots \ldots \ldots \ldots$

I inform by phone

I inform by e-mail

I inform the building administrator

Directly at the PWiK Customer Service Office

I do not inform the company about failures

11. Would you be interested in the following information related to personal water use:

Multiple choice

Characteristics of your own water consumption

Alert in case of improper flows (e.g., leakage) of water in the customer's home

Water meter reading dates

Current chemical parameters of the water

Water temperature

Water pressure

Water supply interruptions

Failures

Payment due date reminder

Information about the prepared invoice

Other (specify) 
Table A1. Cont.

12. What type of contact for receiving the above information would be most appropriate for you?

Multiple choice
Through your smartphone application

Through your own account in E-BOK

Personal contact at the Customer Service Office

By e-mail

Other

(specify)

.....

$\bigcirc \quad$ Yes

No

I don't know
Improved water quality

Ability to share information about the system for continuous improvement

Reducing the number of water network failures

14. W would your expectations be regarding the direction of change in water distribution management?

Multiple choice

15. If you chose the answer "improved water quality" in question 14, please indicate which water parameters you would like to improve?

Multiple choice

16. Whether, and if so to what extent, you consider the operation of the City's sewage treatment plant to be annoying?

PLEASE SELECT ONLY ONE ANSWER

17. If there is any degree of annoyance, what bothers you most?

Multiple choice

18. To what extent do you consider the operation of a sewage pumping station to be annoying?

PLEASE SELECT ONLY ONE ANSWER
Improved communication with the company

Other (specify)

$\begin{array}{lll} & \text { Hardness } & \\ 0 & \text { Taste } & 1 \\ 0 & \text { Smell } & 2 \\ 0 & \text { Purity } & 3 \\ 0 & \text { Other (specify) } & 4 \\ & & 5\end{array}$

$\ldots \ldots \ldots$

Very annoying

Somewhat annoying

I do not feel any negative effects of its functioning (continue to question 18)

$\bigcirc \quad$ Difficult to say (continue to question 18)

Smell

Noise

Traffic during sludge transport

Other

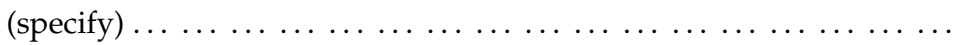
...
Very annoying

Somewhat annoying

I do not feel any negative effects of its functioning

II. Company image and evaluation of pro-social activities

Do you know the following initiatives organized by PWiK to raise environmental awareness? If so, how would you rate them?

19. Art contest on the occasion of the World Water Day for elementary school "Painted on Water"

\section{I don't know}

I know, it is an important initiative

I know, it is difficult for me to assess it

$\bigcirc$ I know, it is an insignificant initiative 
Table A1. Cont.

20. Eco-weekend in the PLAZA shopping center in Rybnik - the theme of sewage treatment

PLEASE SELECT ONLY ONE ANSWER

21. World Hand Washing Day-educational activities in kindergartens in Rybnik

PLEASE SELECT ONLY ONE ANSWER

22. Organizing a photo contest for high school students "Water? Naturally the Best from the Tap!"

PLEASE SELECT ONLY ONE ANSWER

23. Trips to the sewage treatment plant in Rybnik-Orzepowice organized for students

PLEASE SELECT ONLY ONE ANSWER

24. Do you recognize PWiK company logo PLEASE SELECT ONLY ONE ANSWER

25. Do you know any marketing slogans that promote the company?

PLEASE SELECT ONLY ONE ANSWER
I don't know

I know, it is an important initiative

I know, it is difficult for me to assess it

I know, it is an insignificant initiative

\section{I don't know}

I know, it is an important initiative

I know, it is difficult for me to assess it

I know, it is an insignificant initiative

\section{I don't know}

I know, it is an important initiative

I know, it is difficult for me to assess it

I know, it is an insignificant initiative

\section{I don't know}

I know, it is an important initiative

I know, it is difficult for me to assess it

I know, it is an insignificant initiative
Yes (which one(-s))

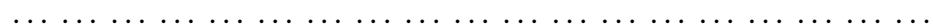

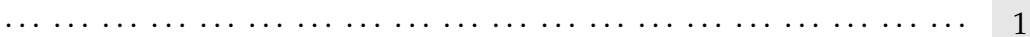

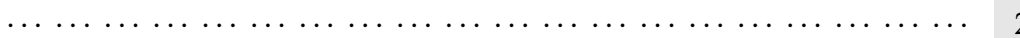
$\ldots \ldots \ldots \ldots$

$\bigcirc \quad$ No
26. Are you familiar with activities for improvement of the environment carried out by PWiK Rybnik?

PLEASE SELECT ONLY ONE ANSWER
Y Yes-please provide an example

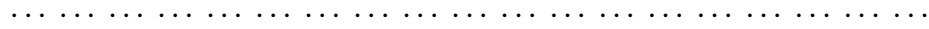

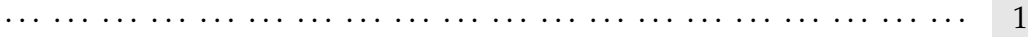

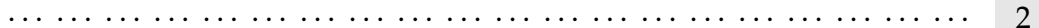

$\ldots \ldots \ldots \ldots$

$\bigcirc \quad$ No
27. What are your suggestions for further could implement? environmental innovations that the company

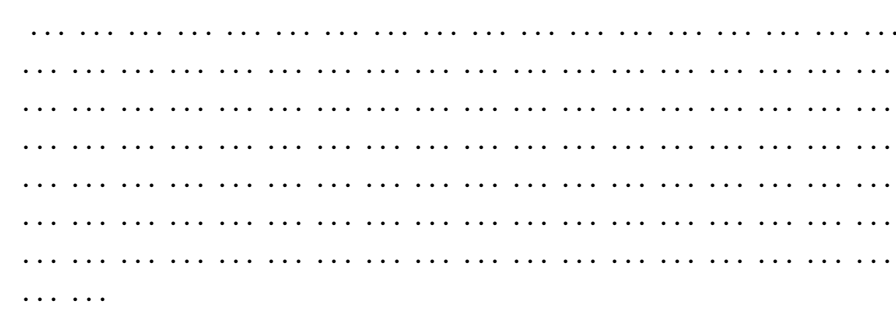

28. Do you recognize the necessity of cooperation between PWiK Rybnik and scientific and research institutes in order to implement improvements in the company's operations?

Yes, such cooperation is necessary today

Hard to say

Rather not necessary (continue to question 30) 
Table A1. Cont.

29. If so, what should be the most important outcome of this collaboration?

PLEASE SELECT ONLY ONE ANSWER

30. Are you familiar with PWiK activities supporting the development of local organizations, e.g., cultural and sports ones?

PLEASE SELECT ONLY ONE ANSWER
Failure-free operation of water supply systems

More efficient sewage treatment plants

Reduction of nuisance associated with wastewater disposal

Modern systems of information exchange between the company

and its customers

Other

(specify)

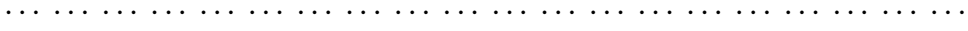

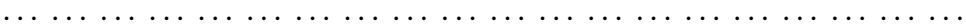

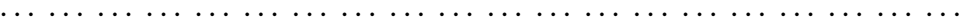

$\ldots \ldots \ldots \ldots$

Y Yes-please provide an example

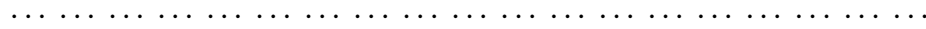

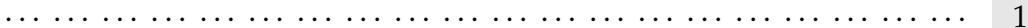

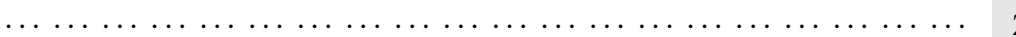

$\ldots \ldots \ldots \ldots$

$\bigcirc \quad$ No

\begin{tabular}{|c|c|c|c|c|c|}
\hline \multicolumn{6}{|c|}{ Particulars } \\
\hline Gender: & $\begin{array}{l}\bigcirc \\
\bigcirc\end{array}$ & $\begin{array}{l}\text { Woman } \\
\text { Men }\end{array}$ & Age: & $\begin{array}{l}0 \\
0 \\
0 \\
0 \\
0\end{array}$ & $\begin{array}{l}\text { up to } 24 \text { years } \\
25-34 \\
35-44 \\
45-54 \\
55 \text { and over }\end{array}$ \\
\hline $\begin{array}{l}\text { Number of persons in the } \\
\text { household (living together) }\end{array}$ & O & 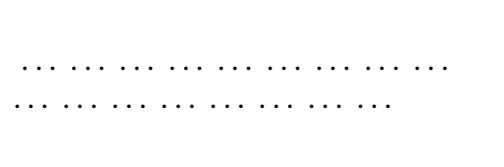 & $\begin{array}{l}\text { What kind of } \\
\text { education do you } \\
\text { have? }\end{array}$ & $\begin{array}{l}0 \\
0 \\
0 \\
0\end{array}$ & $\begin{array}{l}\text { Primary } \\
\text { Secondary } \\
\text { Basic vocational } \\
\text { Higher }\end{array}$ \\
\hline Place of residence-district & 0 & $\begin{array}{l}\ldots \ldots \ldots \ldots \ldots \ldots \ldots \ldots \\
\cdots \ldots \ldots \ldots \ldots \ldots \ldots\end{array}$ & $\begin{array}{l}\text { Type of building } \\
\text { occupied }\end{array}$ & 0 & $\begin{array}{l}\text { Detached single-family } \\
\text { house } \\
\text { Single-family terraced } \\
\text { house } \\
\text { Apartment in a } \\
\text { multifamily building }\end{array}$ \\
\hline $\begin{array}{l}\text { The right to use an occupied } \\
\text { building }\end{array}$ & $\begin{array}{l}0 \\
0 \\
0 \\
0\end{array}$ & $\begin{array}{l}\text { House/owner-occupied apartment } \\
\text { Tenant/cooperative apartment } \\
\text { Lease } \\
\text { Rental }\end{array}$ & $\begin{array}{l}\text { Having a garden } \\
\text { including } \\
\text { allotment }\end{array}$ & $\begin{array}{l}0 \\
0\end{array}$ & $\begin{array}{l}\text { Yes } \\
\text { No }\end{array}$ \\
\hline $\begin{array}{l}\text { Do you have a nonreturnable } \\
\text { water meter? }\end{array}$ & $\begin{array}{l}\bigcirc \\
\bigcirc\end{array}$ & $\begin{array}{l}\text { Yes } \\
\text { No }\end{array}$ & & & \\
\hline $\begin{array}{l}\text { If you checked "No" in the } \\
\text { previous question, please } \\
\text { indicate if you plan to } \\
\text { purchase a nonreturnable } \\
\text { water meter? }\end{array}$ & $\begin{array}{l}0 \\
0\end{array}$ & $\begin{array}{l}\text { Yes } \\
\text { No }\end{array}$ & & & \\
\hline
\end{tabular}




\section{References}

1. Liang, X.; Hu, X.; Meng, H. Truly Sustainability or Hypocrisy: The Effects of Corporate Sustainable Orientation on Consumers' Quality Perception and Trust Based on Evidence from China. Sustainability 2020, 12, 2735. [CrossRef]

2. Pérez, A.; Salmones, M.D.M.G.D.L.; López, C. Corporate Reputation in The Spanish Context: An Interaction Between Reporting to Stakeholders and Industry. J. Bus. Ethics 2014, 129, 733-746. [CrossRef]

3. Kim, Y. Strategic communication of corporate social responsibility (CSR): Effects of stated motives and corporate reputation on stakeholder responses. Public Relat. Rev. 2014, 40, 838-840. [CrossRef]

4. Kuzior, A.; Knosala, B. Changes in perception and implementation of CSR in the polish enterprises. Zeszyty Naukowe Politechniki Śląskiej. Organizacja i Zarządzanie. 2015, 81, 119-129.

5. Amorelli, M.; García-Sánchez, I. Trends in the dynamic evolution of board gender diversity and corporate social responsibility. Corp. Soc. Responsib. Environ. Manag. 2021, 28, 537-554. [CrossRef]

6. García-Sánchez, I.-M.; Raimo, N.; Vitolla, F. Are Environmentally Innovative Companies Inclined towards Integrated Environmental Disclosure Policies? Adm. Sci. 2021, 11, 29. [CrossRef]

7. Rodríguez-Martínez, C.C.; García-Sánchez, I.M.; Vicente-Galindo, P.; Galindo-Villardón, P. Exploring Relationships between Environmental Performance, E-Government and Corruption: A Multivariate Perspective. Sustainability 2019, 11, 6497. [CrossRef]

8. Jonek-Kowalska, I.; Wolniak, R. Economic opportunities for creating smart cities in Poland. Does wealth matter? Cities 2021, 114, 103222. [CrossRef]

9. Pérez, A.; del Mar Garcia de los Salmones, M.; Baraibar-Diez, E. Effects of the Type of CSR Discourse for Utilitarian and Hedonic Services. Sustainability 2020, 12, 4821. [CrossRef]

10. Karwot, J.; Ober, J. Safety Management of Water Economy. Case Study of the Water and Sewerage Company. Manag. Syst. Prod. Eng. 2019, 27, 189-196. [CrossRef]

11. Bowen, H.R. Social Responsibilities of the Businessman; Harper \& Row: New York, NY, USA, 1953.

12. McGuire, J.W. Business and Society; McGraw-Hill: New York, NY, USA, 1963.

13. Sethi, S.P. Dimensions of Corporate Social Performance: An Analytical Framework. Calif. Manag. Rev. 1975, 17, 58-64. [CrossRef]

14. Carroll, A.B. A Three-Dimensional Conceptual Model of Corporate Performance. Acad. Manag. Rev. 1979, 4, 497. [CrossRef]

15. Carroll, A.B. The pyramid of corporate social responsibility: Toward the moral management of organizational stakeholders. Bus. Horiz. 1991, 34, 39-48. [CrossRef]

16. Werhane, P.H. Corporate Social Responsibility, Corporate Moral Responsibility, and Systems Thinking: Is There a Difference and the Difference it Makes. Issues Bus. Ethics 2008, 25, 269-289. [CrossRef]

17. Donaldson, T.; Preston, L.E. The Stakeholder Theory of the Corporation: Concepts, Evidence, and Implications. Acad. Manag. Rev. 1995, 20, 65-91. [CrossRef]

18. Carroll, A.B. Corporate Social Responsibility. Bus. Soc. 1999, 38, 268-295. [CrossRef]

19. Solomon, R.C. Corporate Roles, Personal Virtues: An Aristotelean Approach to Business Ethics. Bus. Ethics Q. 1992, 2, 317-339. [CrossRef]

20. Solomon, R.C. Ethics and Excellence: Cooperation and Integrity in Business; Oxford University Press: New York, NY, USA, 1993.

21. Solomon, R.C. Thinking about Feeling: Contemporary Philosophers on Emotions; Oxford University Press: New York, NY, USA, 2004.

22. Duska, R.; Hartman, E.M.; Kanungo, R.N.; Mendonca, M. Organizational Ethics and the Good Life. Adm. Sci. Q. 1998, $43,713$. [CrossRef]

23. Kuzior, A. Rola CSR w działalności "zrównoważonego przedsiębiorstwa". In Business Innovation-Źródła Przewagi Konkurencyjnej; Bartkowiak, P., Kucęba, R., Eds.; Dom Organizatora: Toruń, Poland, 2016; pp. 307-322.

24. Lulewicz-Sas, A.; Godlewska, J. Assessment of Communication CSR by Polish Water and Sewage Companies. WSEAS Trans. Bus. Econ. 2021, 18, 59-66. [CrossRef]

25. Ishikawa, Y.; Murata, M.; Kawaguchi, T. Globally applicable water quality simulation model for river basin chemical risk assessment. J. Clean. Prod. 2019, 239, 118027. [CrossRef]

26. Agenda 21. Earth Summit: The United Nations Programme of Action from Rio. United Nations. 1992. Available online: https:/ / sustainabledevelopment.un.org/content/documents/Agenda21.pdf (accessed on 12 April 2021).

27. Rio de Janeiro, B. The Future We Want. Outcome Document of the United Nations Conference on Sustainable Development. 2012. Available online: https://sustainabledevelopment.un.org/content/documents/733FutureWeWant.pdf (accessed on 12 April 2021).

28. Kuzior, A. Polskie i niemieckie doświadczenia w projektowaniu i wdrażaniu zrównoważonego rozwoju. Polish and German Experiences in Planning and Implementation of Sustainable Development. Probl. Ekorozw. 2010, 5, 81-89.

29. Commission of the European Communities. Green Paper: Promoting a European Framework for Corporate Social Responsi-bility. Brussels: Commission of the European Communities. 2001. Available online: https://ec.europa.eu/transparency/regdoc/rep/ 1/2001/EN/1-2001-366-EN-1-0.Pdf (accessed on 12 April 2021).

30. European Commission. Communication from the Commission to the European Parliament, the Council, the European Economic and Social Commit-tee and the Committee of the Regions. A renewed EU strategy 2011-14 for Corporate Social Responsibility. 2011. Available online: https://www.europarl.europa.eu/meetdocs/2009_2014/documents/com/com_com(2011)0681_/com_ com(2011)0681_en.pdf (accessed on 12 April 2021). 
31. ISO 26000 Social Responsibility. Available online: https://www.iso.org/obp/ui/\#iso:std:iso:26000:ed-1:v1:en (accessed on 12 April 2021).

32. Weber, O.; Saunders-Hogberg, G. Corporate social responsibility, water management, and financial performance in the food and beverage industry. Corp. Soc. Responsib. Environ. Manag. 2020, 27, 1937-1946. [CrossRef]

33. Cesar, S. Corporate social responsibility fit helps to earn the social license to operate in the mining industry. Resour. Policy 2020, 101814. [CrossRef]

34. Hall, N.L. Community corporate engagement on water resource impacts: Opportunities for Social Licence to Operate. Australas. J. Water Resour. 2015, 19, 109-115. [CrossRef]

35. Kazakova, N.; Kogdenko, V.; Bobkova, M.; Sivkova, A.; Krioni, A. Social responsibility and environmental safety risks mon-itoring of metallurgical companies using an industrial approach. In 20th International Multidisciplinary Scientific GeoConference SGEM 2020; SGEM: Sofia, Bulgaria, 2020; pp. 333-340.

36. Hediger, W. The Corporate Social Responsibility of Hydropower Companies in Alpine Region-Theory and Policy Recommendations. Sustainability 2018, 10, 3594. [CrossRef]

37. Vila, M.; Afsordegan, A.; Agell, N.; Sánchez, M.; Costa, G. Influential factors in water planning for sustainable tourism destinations. J. Sustain. Tour. 2018, 26, 1241-1256. [CrossRef]

38. Jabłoński, A. Trust as a Key Factor in Shaping the Social Business Model of Water Supply Companies. Sustainability 2019, 11, 5805. [CrossRef]

39. Venier, S.; Verde, S. Hera Group: The Path Towards Shared Value and Circularity. In The Italian Utilities Industry; Springer Science and Business Media LLC: Cham, Switzerland, 2020; pp. 139-154.

40. Moya-Fernández, P.J.; López-Ruiz, S.; Guardiola, J.; González-Gómez, F. Determinants of the acceptance of domestic use of recycled water by use type. Sustain. Prod. Consum. 2021, 27, 575-586. [CrossRef]

41. Alvarado-Gómez, E.; Tapia, J.I.; Encinas, A. A sustainable hydrophobic luffa sponge for efficient removal of oils from water. Sustain. Mater. Technol. 2021, 28, e00273. [CrossRef]

42. Izadi, P.; Eldyasti, A. Holistic insights into extracellular polymeric substance (EPS) in anammosx bacterial matrix and the potential sustainable biopolymer recovery: A review. Chemosphere 2021, 274, 129703. [CrossRef]

43. El-Gendy, N.S.; Nassar, H.N. Biosynthesized magnetite nanoparticles as an environmental opulence and sustainable wastewater treatment. Sci. Total Environ. 2021, 774, 145610. [CrossRef]

44. Wilinska-Lisowska, A.; Ossowska, M.; Czerwionka, K. The Influence of Co-Fermentation of Agri-Food Waste with Primary Sludge on Biogas Production and Composition of the Liquid Fraction of Digestate. Energies 2021, 14, 1907. [CrossRef]

45. Kalak, T.; Cierpiszewski, R.; Ulewicz, M. High Efficiency of the Removal Process of $\mathrm{Pb}$ (II) and Cu(II) Ions with the Use of Fly Ash from Incineration of Sunflower and Wood Waste Using the CFBC Technology. Energies 2021, 14, 1771. [CrossRef]

46. Kusch-Brandt, S.; Alsheyab, M. Wastewater Refinery: Producing Multiple Valuable Outputs from Wastewater. J 2021, 4, 51-61. [CrossRef]

47. Plevri, A.; Lytras, E.; Samios, S.; Lioumis, C.; Monokrousou, K.; Makropoulos, C. Sewer Mining as A Basis for Technological, Business and Governance Solutions for Water in the Circular Economy: The NextGen Athens Demo. Environ. Sci. Proc. 2020, 2, 54. [CrossRef]

48. Benites-Zelaya, A.A.; Soler-Cabezas, J.L.; Ferrer-Polonio, E.; Mendoza-Roca, J.-A.; Vincent-Vela, M.C. A Step Forward to the Characterization of Secondary Effluents to Predict Membrane Fouling in a Subsequent Ultrafiltration. Water 2020, $12,1975$. [CrossRef]

49. Karwot, J.; Bondaruk, J.; Zawartka, P. Ocena możliwości wprowadzenia układu kogeneracji w procesie zagospodarowania biogazu na przykładzie oczyszczalni ścieków w Rybniku Orzepowicach. Rocz. Ochr. Środowiska 2020, 22, $1116-1131$.

50. Sakiewicz, P.; Piotrowski, K.; Ober, J.; Karwot, J. Innovative artificial neural network approach for integrated biogas-Wastewater treatment system modelling: Effect of plant operating parameters on process intensification. Renew. Sustain. Energy Rev. 2020, 124, 109784. [CrossRef]

51. Kwilinski, A.; Kuzior, A. Cognitive Technologies in the Management and Formation of Directions of the Priority Development of Industrial Enterprises. Manag. Syst. Prod. Eng. 2020, 28, 133-138. [CrossRef]

52. Kuzior, A.; Kwilinski, A.; Tkachenko, V. Sustainable development of organizations based on the combinatorial model of artificial intelligence. Entrep. Sustain. Issues 2019, 7, 1353-1376. [CrossRef]

53. USTAWA z dnia 6 września 2001 o dostępie do informacji publicznej (Dz. U. 2001 Nr 112 poz. 11980). Available online: https:/ / static1.money.pl/d/akty_prawne/pdf/DU/2001/112/DU20011121198.pdf (accessed on 20 May 2021).

54. Dyrektywa UE 2014/95/UE. Available online: https://www.seg.org.pl/pl/node/5883 (accessed on 20 May 2021).

55. Dyrektywa UE 91/271/EWG. Available online: http://orka.sejm.gov.pl/Drektywy.nsf/all/31991L0271/\$File/31991L0271.pdf (accessed on 20 May 2021).

56. Creswell, J.W. Research Design: Qualitative, Quantitative, and Mixed Methods Approaches; Sage: Los Angeles, CA, USA, 2009.

57. Babbie, E. Survey Research Methods; Wadsworth/Thomson: Belmont, NS, Canada, 1990.

58. Ober, J.; Karwot, J.; Kuzior, A. Pro-social activities and the image of a water and sewage company on the example of PWiK Rybnik. Organ. Manag. 2020, 1, 21-34. 
59. Ober, J.P.; Karwot, J.; Kuzior, A. Nowoczesne Metody Świadczenia Usług Wodno-Kanalizacyjnych Wobec Działań Wyznaczonych Idea Podniesienia Jakości Życia Społeczności Lokalnej Na Przykładzie Branży Wodno-Kanalizacyjnej W Mieście Rybnik. Acta Univ. Nicolai Copernici. Zarzadzanie 2018, 45, 17-26. [CrossRef]

60. Ober, J.; Karwot, J.; Kuzior, A. The process of communication on the client-Enterprise level in the face of activities set by the idea of corporate social responsibility on the example of the water and sewage industry in the city of Rybnik. Ekon. Organ. Przedsiębiorstwa 2018, 12, 125-137.

61. Mynarski, S. Praktyczne Metody Analizy Danych Rynkowych I Marketingowych; Zakamycze: Cracow, Poland, 2000.

62. Urząd statystyczny w Katowicach. Statystyczne Vademecum Samorządowca 2020. Miasto Rybnik. Available online: https: // katowice.stat.gov.pl/vademecum/vademecum_slaskie/portrety_miast/miasto_rybnik.pdf (accessed on 20 September 2020). 